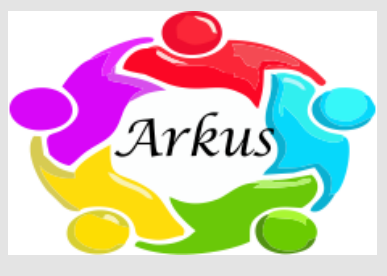

ARKUS

Journal Homepage:

https://hmpublisher.com/index.php/arkus

\title{
The Effect of Murottal Al-Quran Therapy on Pain in Post Cesarean Surgery \\ Patients at Abby Mother and Child Hospital, Lhokseumawe City \\ Anna Millizia ${ }^{*}$, Mardiati², Anita Syafridah ${ }^{3}$ \\ ${ }^{1}$ Department of Anesthesiology and Intensive Therapy, Faculty of Medicine, Universitas Malikussaleh, Lhokseumawe, Indonesia \\ 2 Department of Pediatrics, Faculty of Medicine, Universitas Malikussaleh, Lhokseumawe, Indonesia \\ ${ }^{3}$ Department of Public Health Sciences, Faculty of Medicine, Universitas Malikussaleh, Lhokseumawe, Indonesia
}

\section{A R T I C L E I N F O \\ Keywords: \\ Pain \\ Murottal \\ Koran recital \\ Complementary therapy \\ Numerical rating scale \\ Corresponding author: \\ Anna Millizia \\ E-mail address: \\ anna.millizia@unimal.ac.id}

All authors have reviewed and approved the final version of the manuscript.

\begin{abstract}
A B S T R A C T
Pain is an unpleasant sensory and emotional experience resulting from actual or potential tissue damage or described in terms of the damage. Murottal is a recording of the voice of the Qur'an sung by a qori (reader of the Qur'an). In this study, the degree of pain before murottal therapy was obtained based on the NRS (numeric rating scale) pain measuring instrument by the respondents, it was found that 8 patients (18.6\%) had normal pain levels, 23 people $(53.5 \%)$ experienced mild pain, and 12 people $(27.9 \%)$ experienced moderate pain. Meanwhile, after murottal therapy based on the NRS pain measuring instrument (Numeric Rating Scale) by the respondents, it was found that patients with normal pain levels increased to 28 people (65.1\%), and those who experienced mild pain became 15 people (34.9\%). There is an effect of murottal Al-Qur'an therapy in lowering the pain intensity in post-cesarean patients at RSIA Abby, Lhokseumawe City.
\end{abstract}

https://doi.org/10.37275/arkus.v8i1.129

\section{Introduction}

According to the World Health Organization (WHO), the average standard for sectio caesarea (SC) is about $5-15 \%$ per 1000 births in the world. In government hospitals the percentage is around $11 \%$ while in private hospitals it can be more than $30 \%$. The increase in deliveries by sectio caesarea (SC) in all countries during 2007-2008 was 110,000 per birth throughout Asia. ${ }^{1}$ According to WHO in 2015 for almost the last 30 years the rate of delivery by cesarean section was $10 \%$ to $15 \%$ of all deliveries in developing countries. RISKESDAS data in 2013 stated that the delivery rate for sectio caesarea in Indonesia had passed the WHO standard maximum limit of $5-15 \% .^{2}$

Sectio caesarea delivery rate in Indonesia $15.3 \%$ sample of 20,591 mothers who gave birth in the last 5 years surveyed from 33 provinces. The description of the risk factors for the mother during delivery or caesarean section is $13.4 \%$ due to premature rupture of membranes, $5.49 \%$ due to preeclampsia, $5.14 \%$ due to bleeding, 4.40\% Fetal position abnormalities, $4.25 \%$ due to birth canal. closed, $2.3 \%$ due to uterine 
rupture. ${ }^{3}$

Surgery causes changes in the continuity of body tissues. During the operation, anesthesia is used so that the patient does not feel pain during surgery. However, after the operation is complete and the patient begins to regain consciousness, she will feel pain in the part of the body that underwent surgery. Pain is a subjective sensory and emotional unpleasant associated with actual or potential tissue damage and a description of the condition of tissue damage. The cause of postoperative pain is caused by missing anesthetic drugs and because the postoperative wound is still not recovered. The impact of pain on postoperative patients will increase and affect pain healing so it is necessary to control pain after surgery, which can lead to reduced anxiety, easier breathing and faster mobility. ${ }^{4}$

Pain management is divided into two, namely pharmacological and non-pharmacological. Nonpharmacological management consists of various actions including behavioral and cognitive interventions using physical agents including skin stimulation, transcutaneous electrical nerve stimulation (TENS), acupuncture and placebo administration. Cognitive behavioral interventions include distraction, relaxation techniques, biological feedback (biofeedback), hypnosis and therapeutic touch. Distraction techniques are very effective in diverting pain, this is because distraction is a method in an effort to reduce pain and often makes patients more resistant to pain. 5 One effective distraction technique is Qur'anic murrotal therapy, which can reduce physiological pain, stress, and anxiety by diverting one's attention from pain. ${ }^{4}$ Listening to the holy Quran has a significant effect in reducing reflective nerve tension and these results were recorded and measured quantitatively and qualitatively by computer-based tools. ${ }^{6}$ Murrotal AlQur'an can reduce physiological pain, stress, and anxiety by diverting one's attention from pain. Murrotal Al-Qur'an has been shown to have an effect, namely lowering heart rate, reducing anxiety and depression, relieving pain, lowering blood pressure, and changing the perception of time. ${ }^{7}$ Murrotal produces changes in the state of consciousness through sound, silence, space and time. Murrotal must be heard for at least 15 minutes in order to have a therapeutic effect. 8

\section{Methods}

This study uses quantitative research with the type of pre-experimental research with pre-test and post-test one group design, where observations were made twice, namely before and after the intervention of murottal Al-Quran therapy.The research was conducted at the Abby Mother and Child Hospital, Lhokseumawe City. The parameters to be measured are the pain level of the patient after cesarean section before being given murottal Al Quran therapy and the pain level of the patient after the cesarean section after being given murottal Al Quran therapy. Measuring the level of pain will use a pain measuring instrument NRS (numeric rating scale).

\section{Results and discussion}

The results of the study of 43 patients after cesarean section at RSIA Abby Lhokseumawe city, obtained univariate analysis data that was used to describe the characteristics that existed in patients, namely age and parity status which were stated in the following table. 
Table 1. Distribution of respondents characteristics

\begin{tabular}{|c|c|c|}
\hline \multicolumn{1}{|c|}{ Characteristics } & Frequency (n) & Percentage (\%) \\
\hline Age & & 4.7 \\
\hline$<20$ years & 2 & 76.7 \\
\hline $20-35$ years old & 33 & 18.6 \\
\hline$<35$ years old & 8 & $\mathbf{1 0 0}$ \\
\hline Total & $\mathbf{4 3}$ & 32.5 \\
\hline Parity Status & & 67.5 \\
\hline Primigravida & 14 & $\mathbf{1 0 0}$ \\
\hline Multigravida & 29 & $\mathbf{4 3}$ \\
\hline
\end{tabular}

(Source: Primary data, 2021)

The description of the characteristics of post cesarean surgery patients according to the table above can be seen that the age of the most respondents was in the age range of 20-35 years, as many as 33 respondents (76.7\%) with multigravida parity status at most, as many as 29 respondents (67, $5 \%)$.

Table 2. Distribution of pain degrees before murottal therapy

\begin{tabular}{|l|c|c|}
\hline \multicolumn{1}{|c|}{ Pain before murottal therapy } & Frequency (n) & Percentage (\%) \\
\hline No pain & 8 & 53.5 \\
\hline Mild pain & 23 & 27.9 \\
\hline Moderate pain & 12 & 0 \\
\hline Severe pain & 0 & $\mathbf{1 0 0}$ \\
\hline
\end{tabular}

(Source: Primary data, 2021)

Based on table 2, it was found that the distribution of respondents according to the degree of pain before murottal therapy based on the NRS pain measuring instrument (numeric rating scale) by the respondents, obtained 8 patients with normal pain levels (18.6\%), who experienced mild pain as many as 23 people (53.5\%), and 12 people $(27.9 \%)$. In this study, none of the respondents experienced severe postoperative pain.

Postoperative pain is caused by tissue damage, pain can be indicated by the patient's facial expressions, where facial expressions can determine the value of the pain range in numeric 0-10. Pain can be caused by tissue damage in the body caused by injury, or medical actions such as surgery. Prior to murottal therapy, respondents were in the moderate pain range, this is because analgesic drugs only last for 6 hours and it is hoped that with nonpharmacological therapy with murottal Al-Qur'an the intensity of pain can be reduced. 
Table 3. Distribution of pain degrees after murottal therapy

\begin{tabular}{|l|c|c|}
\hline \multicolumn{1}{|c|}{ Pain after murottal therapy } & Frequency (n) & Percentage (\%) \\
\hline No pain & 28 & 65.1 \\
\hline Mild pain & 15 & 34.9 \\
\hline Moderate pain & 0 & 0 \\
\hline Severe pain $\quad$ Total & 0 & 0 \\
\hline \multicolumn{2}{|c|}{} & $\mathbf{1 0 0}$ \\
\hline
\end{tabular}

(Source: Primary data, 2021)

Based on table 3, it was found that the distribution of respondents according to the degree of pain after murottal therapy based on the NRS (numeric rating scale) pain measuring instrument by the respondents, it was found that patients with normal pain levels increased to 28 people (65.1\%), and those who experienced mild pain became 15 . people (34.9\%). After being given murottal Al-Qur'an therapy, none of the respondents experienced moderate or even severe pain.

The intensity of pain in post-cesarean surgery patients can be reduced or decreased after giving murottal Al-Qur'an therapy for 15 minutes. Because listening to the recitation of the holy verses of the Qur'an is more useful than listening to music and others. The sound of the Qur'an is able to relieve stress, increase relaxation, calmness, comfort and also reduce the intensity of pain. When the patient listens to the reading of the holy verses of the Qur'an that is read well and is listened to with focus, it can cause a sense of calm and comfort for the patient so that pain can be reduced and there is a decrease in the pain scale. By listening to murottal Al-Qur'an, you can also feel physiological changes such as eliminating sadness and gaining inner peace. This also affects a more stable emotional state. A stable emotional state can help relaxation so that the intensity of pain felt by postoperative patients will decrease. Listening to the recitation of the holy verses of the Qur'an is also a form of distraction technique in reducing the degree of pain. The effect of murottal therapy on pain in post-cesarean surgery patients can be seen in table 4 below:

Table 4. Comparison pain level before and after murottal therapy

\begin{tabular}{|l|c|c|}
\hline \multicolumn{1}{|c|}{ Pain Level } & Mean \pm SD & P Value* $^{*}$ \\
\hline Before murottal therapy & $2.09 \pm 0.684$ & 0.000 \\
\hline After murottal therapy & $1.35 \pm 0.482$ & \\
\hline
\end{tabular}

*Wilcoxon statistical test. Source: Primary data, 2021

Based on table 4 above, it can be seen that the results of the Wilcoxon statistical test show a significant value for the level of pain before and after murottal therapy, which is $\mathrm{p}=0.000$, this means that there is a significant difference between the pain score before murottal therapy and the pain score after therapy. murottal. $\mathrm{N}$ indicates the number of samples studied as many as 43 respondents. The conclusion means that there is an effect of murottal Al-Qur'an therapy on pain in post-cesarean patients at RSIA Abby, Lhokseumawe City.

Murottal Al-Qur'an therapy has an influence on the level of pain in postoperative patients, the patient said there was a decrease in the intensity of pain 
experienced after 15 minutes of murottal Al-Qur'an therapy. Patients who listen to the reading of the holy Qur'an feel calm and relaxed, this is because the brain is stimulated to produce a hormone that acts as a decrease in pain intensity. It can also inhibit the production of hormones that trigger increasingly severe pain such as the hormone cortisol. This is in line as according to Potter, music therapy or murottal Al-Qur'an therapy that is listened to for 15 minutes can have a therapeutic effect. 9 Al-Qur'an murottal therapy is proven to be able to activate body cells by converting sound vibrations into waves that are captured by the body and can reduce pain receptor stimulants and provide peace of mind.

If we analyze the sound of the Qur'an, we note that it is an audio frequency or sound wave that is sent through the air to the ear and then enters the brain. After the waves enter the ear and turn into electrical signals and vibrations, they affect the cortex in the brain. After that the brain cells give orders to the body to respond to the sound. ${ }^{10-12}$

\section{Conclusion}

There is an effect of murottal Qur'an therapy in lowering the pain intensity in post-cesarean patients at RSIA Abby, Lhokseumawe city. Hospitals can use murottal therapy as an alternative therapy to reduce pain intensity in postoperative patients.

\section{References}

1. Gibbons L, Belizán JM, Lauer JA, Betrán AP, Merialdi M, et al. The global numbers and costs of additionally needed and unnecessary caesarean sections performed per year. World Health Report. 2010.

2. Ministry of Health RI [Balitbangkes]. National report on basic health research 2013. Ministry of Health. Jakarta.

3. Indonesian Ministry of Health. Sectio caesaria delivery data. Republic of Indonesia. 2019. Jakarta.

4. Potter PA. Concepts, processes and practices. 2006. Jakarta: EGC.

5. Morhenn V, Beavin LE, Zak PJ Massage increases oxytocin and reduces adrenocorticotropin hormone in humans. Alternative Therapies in Health and Medicine. 2012; 18(6): 11-18.

6. Remolda P. The influence of the quran on humans in physiological and psychological perspectives. 2017 ; 8(2): 20-36.

7. Elzaky J. Pocket book of Al-Qur'an reading therapy. Cairo: Shuruq. 2014. https://doi.org/10.1145/31328473132886

8. Nuhan K, Astuti T, Murhan A. the effect of murottal Al-Qur'an on pain intensity in postoperative sectio caesarea patients. Scientific Journal of Nursing Sai Betik. 2018; 14(1): 91. https://doi.org/10.26630/jkep.v14i1.11014

9. Potter PA. AGP Fundamentals of nursing, fundamentals of nursing book 2. 2010. $7^{\text {th }}$ eds. Jakarta: EGC.

10.Barbara CL. Surgical medical treatment; a nursing process approach. YIAP Nursing. $2^{\text {nd }}$ eds. Padjadjaran University: Bandung. 2001.

11.Muliati D. Differences in the effectiveness of murottal therapy and lavender aromatherapy. 2015.

12.Syafei A, Suryadi Y. The effect of giving audio therapy murottal Qur 'an Ar-Rahman verses on anxiety levels in patients with pre-surgery senile cataracts. 2018; 8(1): 126-130. 